\title{
ASSESSING TEACHERS' PERCEPTION ON THE EFFICIENCY (SUCCESS) OF INDUCTIVE APPROACH IN AN ESL/EFL CLASSROOM: GRAMMAR IN CONTEXT
}

\author{
Taj Mohammad \\ Department of English, Najran University, KSA \\ E-mail: tajmohd09@gmail.com \\ Soada Idris Khan \\ Department of English, Najran University, KSA \\ E-mail: khan.soada@gmail.com
}

\begin{abstract}
APA Citation: Mohammad, T., \& Khan, S. I. (2017). Assessing teachers' perception on the efficiency (success) of inductive approach in an ESL/EFL classroom: Grammar in context. English Review: Journal of English Education, 5(2), 197-206
\end{abstract}

Received: 13-03-2017

Accepted: 26-04-2017

Published: 01-06-2017

\begin{abstract}
The present research attempts to assess teachers' perception on the success of using inductive approach in the classroom at Preparatory Year Program, Najran University. It also inquires the difficulties that are usually faced by students (in teachers' opinion) in a grammar class. In order to collect data, 20 teachers were requested to fill in a questionnaire consisting of ten statements (based on key elements of inductive teaching). The questionnaires were analyzed by using 5-Point Likert-scales of agreement. Besides, the researcher also personally interviewed the teachers by using a set of certain questions covering the same theme. The study is divided into two parts; the first part contains detailed analysis and discussion on the statements of the questionnaire and the second part comprises a detailed analysis and discussion on the responses of interview. As results, it is revealed that a majority of teachers supported the use of inductive approach in the classroom because of its learner-centred nature. Inductive methods help students acquire the critical thinking and self-directed learning skills (Prince \& Felder, 2007). However, some teachers (with a negligible percentage) were not so enthusiastic about using inductive approach.
\end{abstract}

Keywords: teachers' perceptions, descriptive and prescriptive grammar, inductive approach

\section{INTRODUCTION}

Inductive approach, an offshoot of direct method of teaching, began to get popularity in academic circles because of its learner-centered nature. Students take charge of their learning and teacher is mere a facilitator in the classroom. This approach motivates students for collaborative learning as students work in pair and groups to learn the language. Inductive approach presents an innovative style of teaching where the new grammatical structures or rules are presented before the students use them in a real language context (Goner, Phillips, \& Walters, 1995). The focus of inductive approach is teaching language in live context so that students may learn not only rules but also their usage in daily life. For example, if the structure to be taught is the comparative form, the teacher would begin the lesson by calling a student (supposedly named Robert) from the class and saying, "This is Robert. He is tall." Then, the teacher would call another taller student (supposedly John) next to the first saying, "This is John. He is taller than Robert." The teacher would then provide many examples using students and items from the classroom, renowned personalities, or anything from the daily life of the students, to create an objective correlative in order to explain the use of the grammatical structure. 
When students themselves are part of learning activities, they take more interest in the business of learning. This way the teacher can present a particular problem/challenge and they work on it in pair and groups. Teachers can also write different examples on the board and ask students to analyse them and acquire rules from the particular structures. This discovery and inquiry-based learning is very advantageous in an EFL/ESL classroom (Goner, Phillips, \& Walters, 1995).

Prescriptive and deductive approaches to English grammar teaching (e.g. pattern drills, rule memorization, etc.) have proved ineffective and boring, because the grammar of a language is acquired not through imitation but through abstracting a set of grammatical rules from language data (Chomsky, 1977, 1986, 1995, 2002). This has been evidenced by many studies on child language acquisition (See Akmajian \& Heny, 1980; Pinker, 1995, 1999; Lightbown \& Spada, 2006).

$$
\text { As Chomsky (1972) points out, "a }
$$
person who knows a language has mastered a system of rules that assigns sound and meaning in a definite way for an infinite class of sentences .... Of course, the person who knows the language has no consciousness of having mastered these rules or of putting them to use ..." (p. 103104). Thus, even a native speaker of English needs formal grammar training though he or she has already acquired a subconscious knowledge of English grammar (Rodgers, 2001; Richards \& Renandya, 2002).

Now, the question is how to teach grammar (an important part of language) effectively so that students can use it accurately in day-to-day discourse. Deductive approach encourages learners mugging up grammatical items. It hardly trains students on using it (grammar) accurately in a given context. In order to achieve these objectives, inductive approach of teaching seems to be more suitable. It discourages the practice of memorizing linguistic items rather it encourages students to use language successfully for communication, one of the most important functions of a language. Inductive methods are all student-centred. It makes learners more responsible for their own learning than the traditional lecture-based deductive approach. They can be characterized as constructivist methods. They rely on the widely accepted principle that students construct their own versions of reality rather than simply absorbing versions presented by their teachers (Prince \& Felder, 2007). These methods, most of the times, involve students discussing questions and solving problems in class (active learning), with much of the work in and out of class are being done by students in groups (collaborative or cooperative learning) (Prince $\&$ Felder, 2007)

Inductive methods motivate students to adopt a deep (meaning-oriented) approach to learning, as opposed to a surface (memorization-intensive) approach (Prince \& Felder, 2007). Inductive teaching methods include many forms like discovery learning, inquiry-based learning, problembased learning, project based learning, casebased teaching, and just-in-time teaching (Prince \& Felder, 2007). If all these aspects of inductive approach are kept in mind, there would be better chances of learning and students will be benefitted at large.

Keeping in mind the advantages of inductive approach, the present research attempts to assess teachers' perception on the success of using inductive approach in the classroom. It inquires the difficulties that are usually faced by students (in teachers' opinion) in a grammar class. Finally, it suggests some remedies to improve teaching of grammar at PYP, Najran University based on the findings of the study.

\section{METHOD}

Twenty EFL teachers (teaching grammar), from PYP, were selected as the participants of the study. Their experience of teaching English varies between 2-20 years. A 
survey questionnaire (containing 10 statements) was developed to gather data from the participants. The aim of the questionnaire was to assess how teachers perceived and rated the current use of inductive approach of teaching at PYP, Najran University. The contents of the questionnaire were based on the key components of inductive approach (as practiced at PYP), using 5-Point Likert-scales of agreement. In addition, an interview session was also conducted to the teachers to have their expert opinion and suggestions. The interview included four key statements on the current (inductive) approach of teaching.

\section{RESULTS AND DISCUSSION}

\section{Questionnaire Analysis}

Table 1. Descriptive statistics of the survey's statements

\begin{tabular}{|c|c|c|c|c|c|c|c|}
\hline $\begin{array}{l}\text { Std. } \\
\text { No. }\end{array}$ & Statements & $\begin{array}{c}5 \\
\text { Strongly } \\
\text { agree }\end{array}$ & $\begin{array}{c}4 \\
\text { Agree }\end{array}$ & $\begin{array}{c}3 \\
\text { Can`t } \\
\text { say }\end{array}$ & $\begin{array}{c}2 \\
\text { Disagree }\end{array}$ & $\begin{array}{c}1 \\
\text { Strongly } \\
\text { disagree }\end{array}$ & Mean \\
\hline 1. & $\begin{array}{l}\text { Students can acquire grammar } \\
\text { if they are exposed to the } \\
\text { target language, without prior } \\
\text { explanation of the rules. }\end{array}$ & $\begin{array}{c}4 \\
20 \%\end{array}$ & $\begin{array}{c}7 \\
35 \%\end{array}$ & $\begin{array}{c}2 \\
10 \%\end{array}$ & $\begin{array}{c}5 \\
25 \%\end{array}$ & $\begin{array}{c}2 \\
10 \%\end{array}$ & 3.3 \\
\hline 2. & $\begin{array}{l}\text { Students can improve the use } \\
\text { of grammatical structures } \\
\text { through constant practice. }\end{array}$ & $\begin{array}{c}5 \\
25 \%\end{array}$ & $\begin{array}{c}9 \\
45 \%\end{array}$ & $\begin{array}{c}2 \\
10 \%\end{array}$ & $\begin{array}{c}4 \\
20 \%\end{array}$ & $\begin{array}{c}0 \\
0 \%\end{array}$ & 3.75 \\
\hline 3. & $\begin{array}{l}\text { Students prefer teachers' } \\
\text { presentation followed by } \\
\text { analysis to explain the rules } \\
\text { of grammatical structures. }\end{array}$ & $\begin{array}{c}6 \\
30 \%\end{array}$ & $\begin{array}{c}12 \\
60 \%\end{array}$ & $\begin{array}{c}2 \\
10 \%\end{array}$ & $\begin{array}{c}0 \\
0 \%\end{array}$ & $\begin{array}{c}0 \\
0 \%\end{array}$ & 4.2 \\
\hline 4. & $\begin{array}{l}\text { Grammar acquisition among } \\
\text { ESL/EFL students does not } \\
\text { involve conscious knowledge } \\
\text { of the grammatical structures } \\
\text { and the rules for their } \\
\text { functioning. }\end{array}$ & $\begin{array}{c}1 \\
5 \%\end{array}$ & $\begin{array}{c}6 \\
30 \%\end{array}$ & $\begin{array}{c}4 \\
20 \%\end{array}$ & $\begin{array}{c}8 \\
40 \%\end{array}$ & $\begin{array}{c}1 \\
5 \%\end{array}$ & 2.9 \\
\hline 5. & $\begin{array}{l}\text { ESL/EFL students do not } \\
\text { need conscious knowledge } \\
\text { of grammar in order to } \\
\text { improve the knowledge of } \\
\text { language. }\end{array}$ & $\begin{array}{c}2 \\
10 \%\end{array}$ & $\begin{array}{c}5 \\
25 \%\end{array}$ & $\begin{array}{c}5 \\
25 \%\end{array}$ & $\begin{array}{c}7 \\
35 \%\end{array}$ & $\begin{array}{c}1 \\
5 \%\end{array}$ & 3 \\
\hline 6. & $\begin{array}{l}\text { The practice of grammatical } \\
\text { structures must always be } \\
\text { performed within context } \\
\text { and never through isolated } \\
\text { examples. }\end{array}$ & $\begin{array}{c}6 \\
30 \%\end{array}$ & $\begin{array}{c}12 \\
60 \%\end{array}$ & $\begin{array}{c}0 \\
0 \%\end{array}$ & $\begin{array}{c}2 \\
10 \%\end{array}$ & $\begin{array}{c}0 \\
0 \%\end{array}$ & 4.1 \\
\hline 7. & $\begin{array}{l}\text { Students do not need to be } \\
\text { acquainted with the form and } \\
\text { function of a certain } \\
\text { grammatical structure before } \\
\text { they use it in context. }\end{array}$ & $\begin{array}{c}1 \\
5 \%\end{array}$ & $\begin{array}{c}7 \\
35 \%\end{array}$ & $\begin{array}{c}3 \\
15 \%\end{array}$ & $\begin{array}{c}7 \\
35 \%\end{array}$ & $\begin{array}{c}2 \\
10 \%\end{array}$ & 2.9 \\
\hline 8. & $\begin{array}{l}\text { Teachers should correct only } \\
\text { those mistakes which } \\
\text { obstruct communication. }\end{array}$ & $\begin{array}{c}7 \\
35 \%\end{array}$ & $\begin{array}{c}6 \\
30 \%\end{array}$ & $\begin{array}{c}1 \\
5 \%\end{array}$ & $\begin{array}{c}5 \\
25 \%\end{array}$ & $\begin{array}{c}1 \\
5 \%\end{array}$ & 3.65 \\
\hline
\end{tabular}




\begin{tabular}{|c|c|c|c|c|c|c|c|}
\hline 9. & $\begin{array}{l}\text { The best way for mastering } \\
\text { grammar is to participate in } \\
\text { activities which refer to } \\
\text { everyday situations. }\end{array}$ & $\begin{array}{c}8 \\
40 \%\end{array}$ & $\begin{array}{c}10 \\
50 \%\end{array}$ & $\begin{array}{c}2 \\
10 \%\end{array}$ & $\begin{array}{c}0 \\
0 \%\end{array}$ & $\begin{array}{c}0 \\
0 \%\end{array}$ & 4.3 \\
\hline 10. & $\begin{array}{l}\text { When grammar is taught } \\
\text { separately from other } \\
\text { language components, } \\
\text { students are not able to apply } \\
\text { such knowledge in everyday } \\
\text { communication. }\end{array}$ & $\begin{array}{c}2 \\
10 \%\end{array}$ & $\begin{array}{c}12 \\
60 \%\end{array}$ & $\begin{array}{c}2 \\
10 \%\end{array}$ & $\begin{array}{c}4 \\
20 \%\end{array}$ & $\begin{array}{c}0 \\
0 \%\end{array}$ & 3.6 \\
\hline
\end{tabular}

Reed (1989) thinks that Likert-type rating scale should be used to generally gather data. Jung, Osterwalder, and Wipf (2000, p. 2) support that "the Likert scale was the only assessment instrument I found that was practical for the classroom.” To interpret the level of means, the researcher applied Siti Rahaya and Salbiah's (1996) model of explaining means. It is summarized in Table 2.

Table 2. Score category breakdown adopted from Siti Rahaya and Salbiah (1996)

\begin{tabular}{cc}
\hline Means & Corresponding level \\
\hline $1.0-1.80$ & Very low \\
$1.81-2.60$ & Low \\
$2.61-3.40$ & Moderate \\
$3.41-4.20$ & High \\
$4.21-5.0$ & Very high \\
\hline
\end{tabular}

The first statement in the questionnaire stating that "Students can acquire grammar if they are exposed to the target language, without prior explanation of the rules" reveals that $20 \%$ of the participants strongly agree to the statement meaning that students can acquire grammar if they are exposed to the target language without prior explanations of the rules. $35 \%$ of the participants agreed to this statement. If these two scales are merged, $55 \%$ of the teachers are in favor of the statement. Then, $10 \%$ of the participants did not express their opinion, $25 \%$ of the participants disagreed, while $10 \%$ of the participants strongly disagreed to the statement. The mean of the statement is 3.3 that lies on the category of 'Moderate' based on the scale by Siti Rahaya and Salbiah (1996).

The second statement in the questionnaire stating that "Students can improve the use of grammatical structures through constant practice" shows that there are $25 \%$ of the participants who strongly agreed to the statement. $45 \%$ of the participants admitted that the students can improve the use of grammatical structures through constant practice. If these two scales are merged, there is a significant percent $(70 \%)$ who accepted the statement. Whereas, $10 \%$ of the participants had no idea, $20 \%$ of the participants disagreed to the statement, and there was none who strongly disagreed to the statement. The mean is categorized as high.

The third statement in the questionnaire stating that "Students prefer teachers' presentation followed by analysis to explain the rules of grammatical structures" proves that $30 \%$ of the participants strongly agreed that students prefer teachers' presentation of examples followed by analysis to the rules of grammatical structures. $60 \%$ of the 
participants agreed to the statement though $10 \%$ of the participants had no opinion. There was none on the disagreement side. The mean is categorized as high.

The fourth statement in the questionnaire stating that "Grammar acquisition among students does not involve conscious knowledge of the grammatical structures and the rules for their functioning" exhibits that there are 5\% of the participants who strongly agreed that grammar acquisition among students does not involve conscious knowledge of the grammatical structures and the rules for their functioning. Besides, $30 \%$ of the participants also admitted to it. In contrast, $40 \%$ of the participants disagreed to the statement, another $20 \%$ had no response, and the other $5 \%$ of the participants strongly disagreed. The mean is ranked as moderate.

The fifth statement in the questionnaire stating that "ESL/EFL students do not need conscious knowledge of grammar in order to improve the knowledge of language" divulges that there are $10 \%$ of the participants who strongly agreed to the statement. $25 \%$ of the participants agreed to the statement though the same number $(25 \%)$ of the participants did not express their opinion. Moreover, $35 \%$ of the participants disagreed while $5 \%$ of the participants strongly disagreed to the statement. The mean is categorized as moderate.

The sixth statement in the questionnaire stating that "The practice of grammatical structures must always be performed within context and never through isolated examples" discloses that there are $30 \%$ of the participants who concurred that practice of grammatical structures must always be performed within context, never through isolated examples. Besides, $60 \%$ of the participants agreed to the statement. Whereas, $10 \%$ of the participants disagreed with the statement. The mean is categorized as high.

The seventh statement in the questionnaire stating that "Students do not need to be acquainted with the form and function of a certain grammatical structure before they use it in context" shows that 5\% of the participants strongly agreed to the statement. Then, $35 \%$ of the participants agreed to the statement and $15 \%$ of the participants had no opinion. In contrast, $35 \%$ of the participants disagreed to the statement and $10 \%$ of the participants strongly disagreement to the statement. The mean is categorized as moderate.

The eighth statement in the questionnaire stating that "Teachers should correct only those mistakes which obstruct communication" unveils that $35 \%$ of the participants were in absolute agreement to the statement that teachers should correct only those mistakes which obstruct communication. $30 \%$ of the participants agreed, while $5 \%$ of the participants did not state an opinion. Moreover, $25 \%$ of the participants did not agree with the statement and $5 \%$ were in absolute disagreement. The mean falls in the category of high.

The ninth statement in the questionnaire stating that "The best way for mastering grammar is to participate in activities which refer to everyday situations" reveals that $40 \%$ of the participants thought that the best way for mastering grammar is to participate in activities which refer to everyday situations. $50 \%$ of the participants agreed with the statement. If these two scales (strongly agree and agree) are merged, there is a significant number $(90 \%)$ of participants who favor the statement. Whereas, $10 \%$ of the participants do not give an opinion and there was none of disagreement. The mean is placed as high.

The tenth statement in the questionnaire stating that "When grammar is taught separately from other language components, students are not able to apply such knowledge in everyday communication" reveals that $10 \%$ of the participants strongly agreed with the statement. In line with this, $60 \%$ of the participants agreed to it. If these two scales (strongly agree and agree) are merged, there is a significant number $(70 \%)$ of participants who 
favor the statement. In contrast, $10 \%$ of the participants did not express their opinion and $20 \%$ of the participants did not agree to the statement. The mean is ranked as very high.

The above analysis of the teachers' opinion (through questionnaire statements) affirms that teachers believe in the fact that the use of inductive approach in teaching grammar is more suitable in an EFL/ESL classroom. As it can be seen in the table above that the mean of five statements out of ten is high while one statement is in the category of very high. The rest of four statements fall in the category of moderate. Besides, it is also observed (during the study) that some teachers were not in favour of using inductive approach in the classroom. They (a minority) believed more in deductive approach. They argued that students are too weak to follow inductive approach in the classroom. They also favoured the use of mother tongue in the classroom. If they do not use mother tongue in the classroom, there would be no learning at all. They strongly advocated the use of GT method in the classroom.

However, one cannot deny the fact that the teachers who used DT method and inductive approach have also used the learners' mother tongue although they prefer to provide all the instructions in the target language. They reported that they felt difficulties in the beginning classes but gradually there was improvement in the performance of the students as the learners had begun to understand English. That is the essence of teaching the target language. What learners need is an exposure to the target language. If they are not provided with a good exposure, it would be difficult for them to learn English in a better way.

Finally, the result of the questionnaire shows that most of the teachers are in favour of inductive approach of teaching in the classroom. They opine that teaching grammar (using inductive approach) with innovative ways can yield to fruitful results. Despite unfavourable opinion of some of the faculty members, this approach is widely used by a majority of teachers at PYP, Najran University.

\section{Interview analysis}

Beside the questionnaire, interview was also used as a technique to collect the data needed. In interview session, the participants responded to the following questions:

1. Inductive approach must be used to teach grammar at PYP.

2. Mention some common difficulties that the students face (in teachers' opinion) while using inductive approach in a grammar class!

3. Mention some challenges that the teachers face during teaching grammar inductively.

4. Give some suggestions for improving the teaching grammar inductively.

Table 3. Results of Interview Question 1 (\#Q1)

\begin{tabular}{ccc}
\hline \#Q1 & Number of teachers & Inductive approach must be used to teach grammar at PYP \\
\hline 15 & Yes \\
\hline 5 & No \\
\hline
\end{tabular}

As shown in Table 3, in response to the first question, 15 teachers out of 20 agreed that inductive approach must be used to teach grammar at PYP, Najran University. But, there are still 5 teachers who do not believe in the efficiency of inductive approach to teach grammar. They are the ones who share the target language of the learners and feel more comfortable in teaching L2 with the help of L1. 
Table 4. Results of Interview Question 2 (\#Q2)

\begin{tabular}{cc} 
\#Q2 $\begin{array}{c}\text { Number of } \\
\text { participants }\end{array}$ & \multicolumn{1}{c}{$\begin{array}{c}\text { Mention some common difficulties that the students face } \\
\text { (in teachers' opinion) while using inductive approach } \\
\text { in a grammar classroom }\end{array}$} \\
\hline 8 & $\begin{array}{c}\text { - Too difficult to overcome effect of mother tongue. } \\
\text { - Negative transfer. } \\
\text { - Learning grammar structures which are not present in their mother } \\
\text { tongues such as committing mistakes in perfect and perfect } \\
\text { continuous tenses. }\end{array}$ \\
& $\begin{array}{l}\text { - Poor analytical skills. } \\
\text { - No background knowledge on usage of grammar rules. }\end{array}$ \\
\hline 6 & - No room for group learning because of abundance of syllabus. \\
\hline
\end{tabular}

As shown in Table 4, in response to the second question, there were varied responses but some of the responses were common. The teachers mentioned some common difficulties that the students face (in their opinion) while using inductive approach in a grammar class. Teachers opine that it was too difficult for the students to overcome interference of their mother tongue. Students had been usually taught through GT method by following deductive approach in the classroom. Though they knew the advantages of inductive approach, it was difficult for them to adapt the completely changed pattern of teaching. As the grammar of English and Arabic do not share the same structural pattern (SVO), teaching with the help of mother tongue often results into negative transfer. It creates more problems in acquiring the target language. Moreover, learning grammatical structures, which are not present in their mother tongue, create more confusion for students. For example, students usually commit mistakes in perfect and perfect continuous tenses, as these tense are not part of Arabic language. Most of students have poor analytical skills, while the success of inductive approach depends on the analytical and argumentative skills of the students. Students hardly have any background knowledge on usage of grammar rules. This also makes use of inductive approach difficult in the classroom. Some teachers also stated that there is too much syllabus to be covered in one semester. Therefore, this is also one of the reasons that teachers cannot use all methods of inductive approach like discovery learning, inquiry-based learning, problem-based learning, project based learning, case-based teaching, and just-intime teaching. Teachers hardly have choices. It requires time to experiment all these techniques. Teaching, at PYP, is completely syllabus-oriented.

Table 5. Results of Interview Question 3 (\#Q3)

\begin{tabular}{ccc}
\hline \#3 & $\begin{array}{c}\text { Number of } \\
\text { Participants }\end{array}$ & \multicolumn{1}{c}{$\begin{array}{c}\text { Mention some challenges that the teachers face } \\
\text { during teaching grammar inductively. }\end{array}$} \\
\hline 5 & $\begin{array}{l}\text { - Low comprehension level. } \\
\text { - Making students apply grammatical knowledge in linguistic } \\
\text { communication. }\end{array}$ \\
\hline 6 & $\begin{array}{l}\text { - Lack of commitment on part of students. } \\
\text { - Lack of enthusiasm/motivation. }\end{array}$ \\
\hline 5 & $\begin{array}{l}\text { - Heterogeneous group of students. } \\
\text { - Students understand grammar through structures related to their } \\
\text { mother-tongue. }\end{array}$ \\
\hline
\end{tabular}




\begin{tabular}{l}
\hline $4-$ Teachers are unable to use the target language completely because of \\
the poor background of students (in language). \\
- Teachers face problems in using direct method of teaching because \\
students are too weak to understand the basic structure of the \\
language.
\end{tabular}

As shown in Table 5, in response to question number 3, the teachers mentioned some challenges that they faced during the teaching of grammar inductively. Most of the common challenges that the teachers usually faced are low comprehension level of students, their inability to apply grammatical knowledge for communication purposes, lack of commitment on part of students, lack of enthusiasm/motivation, heterogeneous group of students, and students' comprehension of grammar through structures related to their mother tongue.

The results exhibit that students' level is too low. There is no entrance system at PYP level. That is the reason why there is a variety of learners in the classroom with major differences in their learning performances and temperaments. There must be an entrance system and students should be categorized accordingly. Remedial classes for weak students should be arranged.

Table 6. Results of Interview Question 4 (\#Q4)

\begin{tabular}{cc} 
\#Q4 $\begin{array}{c}\text { Number of } \\
\text { participants }\end{array}$ & $\begin{array}{c}\text { Suggestions for improving teaching of } \\
\text { grammar inductively. }\end{array}$ \\
\hline 4 & - Using multimedia/ technology in the classroom. \\
\hline 4 & $\begin{array}{l}\text { - Maximum pragmatic exposure to the target language. } \\
\text { - Daily practice of grammar exercises in proper context. }\end{array}$ \\
\hline 3 & $\begin{array}{c}\text { - Developing "intuitive grammar" among students. } \\
\text { - Lessons should be based on real life situations. } \\
\text { - Students should be categorized among different levels like } \\
\text { beginner, intermediate, advanced etc. }\end{array}$ \\
& $\begin{array}{c}\text { - Teachers should involve students in classroom activities based on } \\
\text { everyday situations. }\end{array}$ \\
\hline 5 & $\begin{array}{l}\text { - Students should be acquainted with the basics of grammar and } \\
\text { then emphasis should be given to communication skills. } \\
\text { - Situational language teaching. } \\
\text { - More practice of grammar rules with worksheets, handouts (other } \\
\text { than the prescribed book), etc. }\end{array}$ \\
\hline
\end{tabular}

As shown in Table 6, in response to the fourth question, the teachers provided some noteworthy suggestions for improving teaching of grammar inductively. They opined that teachers should involve students in classroom activities based on everyday situations. This is true that maximum pragmatic exposure to the target language can make them feel comfortable with the target language.

Daily practice of grammar exercises in proper context will help students use grammar contextually. Using multimedia/ technology in the classroom is also a good idea. Developing "intuitive grammar" among students can help but it requires a lot of practice.

Besides, students should be categorized into different levels based on their own language proficiency like beginner, intermediate, advanced, etc. A placement test must be conducted to place students in different categories. Then, students should be acquainted with the basics of grammar and 
then emphasis should be put on communication skills. This is a pedagogical issue and teachers should keep this in mind. Situational language teaching can help students use grammar in proper context. Moreover, more practice of grammar rules with worksheets or hand-outs (other than the prescribed book) may be supportive because most of the times the students feel bored with the same textbook causing loss of creativity.

\section{CONCLUSION}

To conclude, it is determined, that most teachers believe on the efficiency (success) of inductive approach in an ESL/EFL setting. The questionnaire and interview methods as used in the study support the idea. There is no doubt that inductive approach is more suitable in context of PYP, Najran University than deductive approach. In addition, the researchers have also taken into consideration the views of a minority of teachers. This is also true that learners are too weak and it becomes difficult to teach them without taking help of mother tongue. However, this is not going to affect their use of inductive approach of teaching. They can still follow inductive approach as it is a technique to carry out the teaching successfully and expanding the students' critical thinking skill. To close, there are also several suggestions provided by the majority of teachers to tackle this problem. If these suggestions are taken into account, it will be easier to follow inductive approach in the classroom especially in a grammar class.

\section{REFERENCES}

Akmajian, A. D., \& Heny, F. (1980). An introduction to the principles of transformational syntax. Retrieved from: https://mitpress.mit.edu/books/introductionprinciples-transformational-syntax.

Chomsky, N. (1972). Language and mind. New York: Harcourt Brace Jovanovich.

Chomsky, N. (1977). Essays on form and interpretation. New York: North Holland.

Chomsky, N. (1986). Knowledge of language: Its nature, origin, and use. New York: Praeger.
Chomsky, N. (1995). Language and thought. London: Moyer Bell.

Chomsky, N. (2002). On nature and language. Cambridge: Cambridge University Press.

Goner, Phillips, \& Walters. (1995). Teaching practice handbook: Structures, grammar and function. Heinemann, 129-138.

Jung, T., Osterwalder, H., \& Wipf, D. (2000). Teaching and assessing middle-year students' speaking and listening skills. Teaching and Learning Research Exchange. Retrieved from: http://www.mcdowellfoundation.ca/main_mcd owell/projects/research_rep/52_teaching_asses sing.pdf.

Lightbown, P., \& Spada, N. (2006). How languages are learned. Oxford: Oxford University Press.

Pinker, S. (1995). The language instinct: How the mind creates language. New York: HarperCollins.

Pinker, S. (1999). Words and rules: The ingredients of language. New York: Basic Books.

Prince, M., \& Felder, R. (2007). The many faces of inductive teaching and learning. Journal of College Science Teaching, 36(5), 14-20.

Reed, V. (1989). Adolescent language disorders: General strategies for teaching language comprehension/listening. Eau Claire, WI: Thinking Publications.

Richards, J., \& Renandya, W. (2002). Methodology in language teaching: An anthology of current practice. Cambridge: Cambridge University Press.

Rodgers, T. (2001). Approaches and methods in language teaching. Cambridge: Cambridge University Press.

Siti Rahaya, A., \& Salbiah, M. (1996). Pemikiran guru cemerlang: Kesan teradap prestasi pengajaran. Fakulti pendidikan, Universiti Kebangsaan Malaysia, Bangi. 


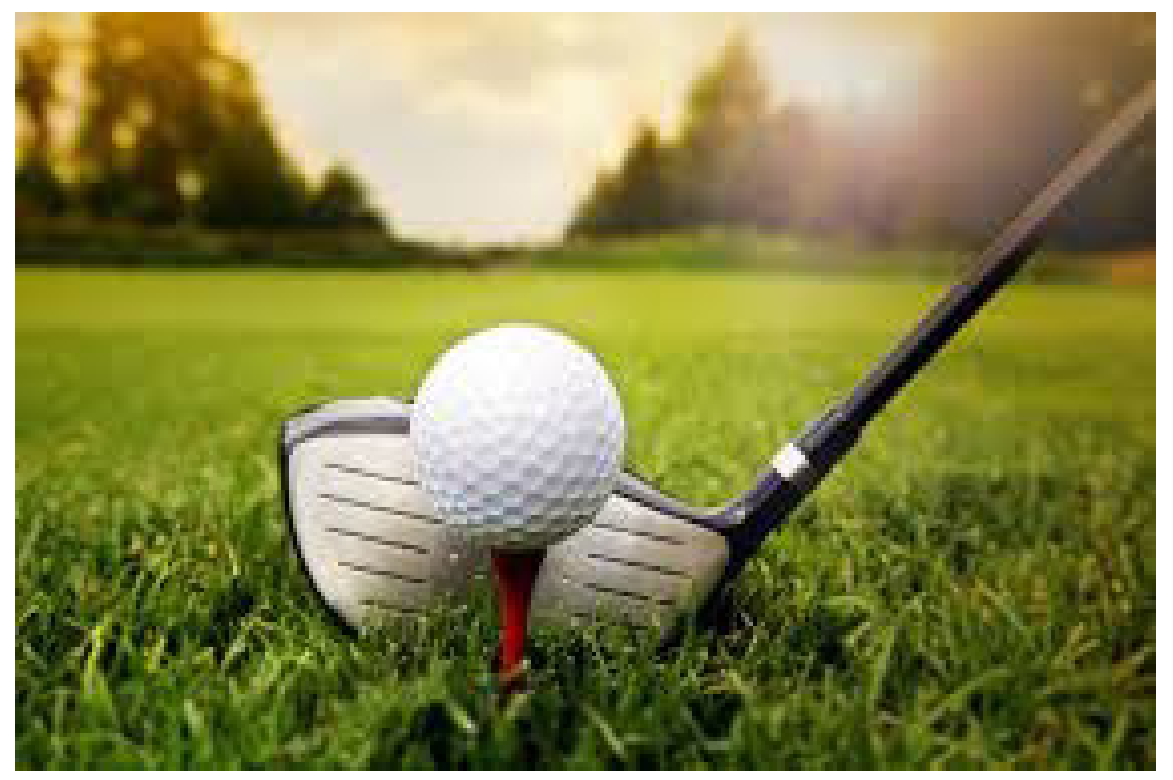

\section{Golf Ball}

Two Golfers were approaching the first tee.

The first guy goes into his golf bag to get a ball and says to his friend - "Hey, why don't you try this ball." He draws a green golf ball out of his bag. "Use this one - You can't lose it!" His friend replies, "What do you mean you can't lose it?!!"

The first man replies, "I'm serious, you can't lose it. If you hit it into the woods, it makes a beeping sound, if you hit it into the water it produces bubbles, and if you hit it on the fairway, smoke comes up in order for you to find it."

Obviously, his friend doesn't believe him, but he shows him all the possibilities until he is convinced. The friend says, "Wow! That's incredible! Where did you get that ball?" The man replies, "I found it."

(Source: http://www.study-express.ru/humour/funny-stories.shtml, picture: www.google.co.id) 